\title{
The Shifting View on the Prohibition of Exogamous Marriage among the Suku Anak Dalam Community
}

\author{
Rahmi Hidayati ${ }^{1}$, Ramlah ${ }^{2}$
}

\begin{abstract}
The Shifting View on the Probibition of Exogamous Marriage among the Suku Anak Dalam Community. There have been many previous studies discussing on the theme of prohibition of endogamy and exogamous marriages, but this study will be more focused on the examining exogamous marriages in traditional societies among the Suku Anak Dalam community in Jambi Province. This study uses a combination of descriptive-empirical methods and literature studies. They are used to describe the results of several interviews with the informants and also supported by the literature studies related to the research objective. This study presents the results of empirical research on the determinant factors that influences the shifting of the perspective change on exogamous marriage among the Suku Anak Dalam community, which is analyzed through sociological and anthropological approaches. The result of this study shows that there have been social changes among the Suku Anak Dalam community in the field of family law, especially in matters of marriage law. The change of time, education, economy, religion, and the development of modern society have implicaton to the change of the paradigm of thinking among some of the Suku Anak Dalam community regarding on the prohibition of exogamous marriages.
\end{abstract}

Keywords: shifting, marriage, ecogamy, endogamy, Suku Anak Dalam

\begin{abstract}
Abstrak: Pergeseran Pandangan Tentang Larangan Perkawinan Eksogami di Masyarakat Suku Anak Dalam. Telah banyak penelitian sebelumnya membahas tentang tema pelarangan perkawinan endogami dan perkawinan eksogami, namun penelitian ini akan lebih difokuskan pada kajian perkawinan eksogami pada masyarakat adat pada masyarakat Suku Anak Dalam di Provinsi Jambi. Penelitian ini menggunakan kombinasi metode deskriptif-empiris dan studi literatur. Metode ini digunakan untuk mendeskripsikan hasil beberapa wawancara dengan informan dan juga didukung oleh studi pustaka terkait dengan tujuan penelitian. Penelitian ini memaparkan hasil penelitian empiris mengenai faktor-faktor determinan yang mempengaruhi pergeseran cara pandang perkawinan eksogami pada masyarakat Suku Anak Dalam, dianalisis melalui pendekatan sosiologis dan antropologis. Hasil penelitian ini menunjukkan bahwa telah terjadi perubahan sosial pada masyarakat Suku Anak Dalam dalam bidang hukum keluarga khususnya dalam masalah hukum perkawinan. Perubahan zaman, pendidikan, ekonomi, agama, dan perkembangan masyarakat modern berimplikasi pada perubahan pola pikir sebagian masyarakat Suku Anak Dalam tentang larangan perkawinan eksogami.
\end{abstract}

Kata Kunci: pergeseran, perkawinan, eksogami endogami, Suku Anak Dalam

${ }^{1}$ Faculty of Sharia and Law, UIN Sulthan Thaha Saifuddin, Jambi, Indonesia

${ }^{2}$ Faculty of Sharia and Law, UIN Sulthan Thaha Saifuddin, Jambi, Indonesia

E-mail: ${ }^{1}$ rahmihidayati@uinjambi.ac.id, ${ }^{2}$ ramlah@uinjambi.ac.id 


\section{Introduction}

Islamic law or known as sharia and fiqh is widely understood as a the whole of Islamic legal rules for all Muslims without exception, which Islam, as a dogma, is believed have absolute and universal values that apply throughout the ages and always dynamic in facing every social change in society, especially when it is facing with the various customs, habits, and traditions. ${ }^{1}$

As the oldest law in the history of Islamic law in Indonesia, marriage law is followed by family law, in which Islamic family law is basically an integral part of Islamic law that regulates various interpersonal relationships in a Muslim family, which consists of marriage law, inheritance law, and child guardianship. Islamic family law has become part of the national legal system in Indonesia and it is heavily influenced by local customary law. $^{2}$

Talking about the marriage law in Indonesia, especially in the Suku Anak Dalam community, it is inseparable from the three systems of marriage law that have influenced the development of marriage law in Indonesia such as customary law, Islamic law, and Positive law. Even though the laws or norms in society are different in the regulation, procedure, and contract process, but all of them have the same goal, namely to create a happy family for each couple.

According to Jambi custom, marriage is not a matter for the two parties, but it is the obligation of each parent, their mother's grandmother, and their family (Tengganai). Like regulated in the family law, it is part of the debts for their parents, especially the father, who has an authority to deliver their children to go to married, especially to his daughter.

${ }^{1}$ Muwahid Shulhan, 'Rekonstruksihukum Islam Dan Implikasi Sosial Budaya Pasca Reformasi Di Indonesia', KARSA: Journal of Social and Islamic Culture, 20.2 (2013), 176-96 (p. 177) <https://doi.org/10.19105/karsa.v20i2.41>.

${ }^{2}$ Regarding on the incarnation of adat into a legal system, as stated by Soepomo, it is evident in the decision of the legal officer. For example, decisions of village groups, decisions of customary chiefs, village peace judges, religious officials, and so on. If the judge finds regulations that must be defended by the customary chief and other legal officers, then those customary regulations are clearly legal.Soekanto, Meninjau Hukum Adat Indonesia, Suatu Pengantar Untuk Mempelajari Hukum Adat (Jakarta: Rajawali Press, 1981), p. 2. 
It means that the obligation of the parents is to deliver their children, especially to their daughter. ${ }^{3}$

Marriage has a very significant position both socially and religiously, including from a legal point of view. ${ }^{4}$ Based on the reason, it can be understood that Islamic marriage law regulates the issue of marriage comprehensively in stages, systematically, and eternally. It is also said to be gradual because before someone is going to married, he or she need to understand the marriage law contract and choosing the wife or husband candidates firstly before going to be a couple in marriage relationship. The selection of wife or husband candidate is a very important aspect even though it is not obligatory in Islam..$^{5}$ In determining a life partner, Islam provides guidance based on the principle of equivalence or kafäah in fiqh al-munākahāt. ${ }^{6}$

Among the Suku Anak Dalam community, marriage adheres to an endogamy system, which requires a person to find a partner in their social environment, family, social class, or neighborhood. They emphasize that marriage is carried out among the Suku Anak Dalam and are prohibited from marrying someone who is not from the Suku Anak Dalam. Even if this happens, there will be legal consequences that will be imposed to those who violate the customary law. ${ }^{7}$

Along with changing times, advances in the level of education, the flows of information and technology, as well as the increase in the community's economy, have resulted to the shift of mindset, awareness, and attitudes of the community regarding on the prohibition of marriage,

\section{p. 44.}

${ }^{3}$ Anonim, Buku Pedoman Adat Jambi (Jambi: Lembaga Adat Province of Jambi, 1994),

${ }^{4}$ Muhammad Amin Suma, Hukum Keluarga Islam Di Dunia Islam, (Jakarta: Raja Grafindo Persada, 2004), p. 81.

${ }_{5}^{5}$ Asrorun Ni'am, Fatwa-Fatwa Masalah Pernikahan Dan Keluarga (Jakarta: Graha Paramuda, 2008), p. 12.

${ }^{6}$ Etymologically, kafäah means equal, balanced, and similar. While in the terminology of fiqh mu'amalah, kafäah means the equivalent, balance, and harmony between the prospective wife and husband, both in physical, position, social status, morals and wealth so that each candidate feels comfortable and suitable and does not feel burdened to carry out a marriage and realizing the goal of marriage.

${ }^{7}$ Munthalib, Suku Anak Dalam Di Pinggiran Kawasan Hutan Lindung Taman Nasional Bukit XII Propinsi Jambi (Serang: A Empat, 2014), p. 116. 
including the left of the endogamy system gradually to be abandoned by some people of the Suku Anak Dalam community. Such shifts and changes as revealed in the above phenomena, according to Kingsley, were quoted by Selo Soemardjan, referred to as social change, namely "changes that occur in the structure and function of society". Cultural changes occured in the Suku Anak Dalam community are a necessity and cannot be avoided, because every society is never static, always dynamic, and changes from one to another condition through various factors. However, this change may be intended as a form of human response to environmental challenges.

Referring to the above description, it seems that the problems faced by the Suku Anak Dalam community are formed and resulted these shifts and changes through positive and negative values, including destroying their pattern of order, resulted in disrupted the social structures and unbalanced life and waning of the Suku Anak Dalam identity like simply seen in marriage exogamy system. This also causes a shift of the cultural values among the Suku Anak Dalam, which is carried out from generation to generation by their ancestors. Based on the above phenomena, it is very necessary to identify the determinant factors that influence the shift of the Suku Anak Dalam view on the prohibition of exogamous marriages.

\section{The Origin of Suku Anak Dalam Community}

Suku Anak Dalam is part of an isolated community group in Jambi Province with a total population of 1840 households or 6940 people. This population usually spreads to occupy in land areas in three districts, such as Batanghari, Tebo, and Sarolangun Regency. Within those areas, they maintain their own way of life which is inherited by their ancestors. ${ }^{10}$

Based on the historical background, the Suku Anak Dalam is often called the Kubu, who is still traditional community in Jambi Province

${ }^{8}$ Selo Soemardjan, Perubahan Sosial Di Yogyakarta (Yogyakarta: Gajah Mada University Press, 1990), p. 336.

9 'Central Bureau of Statistics', (Jambi, 2020).

${ }^{10}$ Robert Aritonang, Pengetahuan Lokal Orang Rimba Dan Implikasinya Pada Strategi Berburu Dan Meramu (Jakarta: Ministry of Enviroment Republic of Indonesia, 2004), p. 122. 
with the full of mystery, even until now, no one else can confirmed exactly about the origin of the Suku Anak Dalam, which their origins are still fully in various questions. There are only a few theories and stories by word of mouth of the descendants can reveal a little of their history.

Based on some literature and research, there are three mentions of Suku Anak Dalam, because the names contain different meanings, such as:

1. Kubu is the most popular term used, especially by Malays and the international community. Kubu in Malay means stupid, kafir, dirty, and disgusting. The term Kubu has already become popular, especially in the writings of Colonial Officials and Ethnographers at the beginning of this century;

2. Suku Anak Dalam is a term used by the Indonesian government through the Ministry of Social Affairs and the term also used by this ethnic group to refer to itself. The meaning of this term is to show their identity as the traditional ethnic group that develops a culture that cannot be separated from the forest. Suku Anak Dalam means an underdeveloped person who lives in the forest, which is in the perspective of the government they must be modernized by removing them from the forest and resettling them through empowerment programs for Remote Indigenous Communities;

3. Orang Rimba. This designation is the most proportional and objective view because it is based on the concept of the Suku Anak Dalam itself. The origin of the mention of Orang Rimba was first published by Moentalib Soetomo in 1995 in his dissertation entitled Orang Rimbo: A Structural-Functional Study on Isolated Communities in Makekal, Jambi Province.

According to Fachruddin Saudagar's research, there are several opinions regarding on the origin of the Suku Anak Dalam. The first opinion says that the Suku Anak Dalam live in the Sarolangun Bangko, who area originated from Rejang Lebong because the dialect of their daily spoken language has similar with the Rejang language. The second opinion says that they live in the Bungo Tebo area that comes from Minangkabau because the dialect of the spoken language is similar with the Minangkabau language. The third opinion states that they live in the 
Batanghari area that comes from Palembang because the dialect of the spoken language is similar with Palembang. The fourth opinion states that they are the original people of Jambi who are very closely related to the ancient Malay and Srivijaya Kingdoms in the past. ${ }^{11}$

According to Muchlas, the origin of the Suku Anak Dalam in Jambi Province was developed from region to region and district. For the Mersam area, Batanghari Regency, Bengkal River and Tabir District, Sarolangun Regency, they are noted that in the ancient times, there were three brothers who opened fields. After finishing clearing the fields for some reason there was a rather fierce quarrel between her sister and brother. The end of the fight resulted in the sister refusing to return to the hamlet, but living in the forest, while their vowing: "It is better to weave kuwau, goats for deer, sweeten the water in the bungkal, draped mosquito net, and covered in lumt, but they are not to return in the light" ${ }^{12}$

According to the version of the Ministry of Social Affairs in the data and information of the Indonesian Ministry of Social Affairs (1990), there is stated that the origin of the Suku Anak Dalam or Orang Rimba, they have known since 1624 during the Palembang Sultanate and the Jambi Kingdom which are actually still one family, have indeed continued to fight and conlfict until the beginning of fighting in Air Hitam area in 1629. This version shows that why there are two ethnic groups of the Suku Anak Dalam today with different languages, physical forms, dwellings, and customs. They are who live in Musi Rawas, South Sumatra and speak Malay, identified have yellow skin and the posture of the Mongoloid race like the Palembang people today. They are also descendants of Palembang troops. ${ }^{13}$

${ }^{11}$ Fachruddin Saudagar, 'Masyarakat Kubu Di Jambi', in Profil Masyarakat Hukum Adat Tradisional Di Nusantara Dari Aceh Sampai Papua, (t. penerbit, t.t), p. 99.

12 The meaning of the oath is she did not want to go back to the hamlet at all, while her two brothers could not prevent it, even though she had been seduced in all kinds of ways, but she still wanted to live in the forest, isolate herself from the bustling life in the hamlet Mukhlas, Tambo Anak Dalam (Jambi: NP, t.t.), pp. 5-11.

${ }^{13}$ Seloa dan Meliani, Masyarakat Terasing Suku Anak Dalam (Jakarta: Direktorat Bina Masyarakat Terasing, 1998). 
Another group lives in the forest area of Jambi Province with the brown skin, curly hair, and deep eyes. It is said that they were mercenaries from the Kingdom of Jambi from another country. Another version is also talking about the story of the Jambi War defended by Suku Anak Dalam, lead by Raden War. Raden War is the grandson of Raden Nagasari. During the guerrilla warfare period, Suku Anak Dalam became very well known as the Kubu, which means the people did not want to surrender or always fighting to the Dutch Colonialists who carried diseases away in the form gun fires.

Until now, the origin of the Suku Anak Dalam is still known existing in Palempang, Nyogan, and Muara Paris, Batanghari Regency. According to the parent opinion of of their group and people, they are understood having a lot customs. They said to have come from 16 Ilir (15 and 16). During the Ducth Colonial period, Palembang (Sriwijaya fell to Majapahit) they fled to Uluan Palembang such as Belido, Besemah, and so on. From there, they ran to Banyu Lincir then through following a small river until they got to where they are now living. ${ }^{14}$

If we examined from the various versions above, we can emphasize that until now there are not yet scientifically explanation about the origin of the Suku Anak Dalam. However, if it is seen from various sources and literatures, the Suku Anak Dalam may be grouped into three above versions which share in the same origin of the Suku Anak Dalam.

\section{Marriage Among the Suku Anak Dalam Community}

In general, marriage is carried out to maintain the existence of the continuity of human life. In Jambi custom, marriage is not a matter for both parties to the prospective couple, but it is the obligation of their parents, grand parents, and families. As explained in the family law, it is a kind of debts for the parents, especially their father "to deliver their children to get a married, especially their daughter". It means that the obligation of the parents to the children is delivering their children to the level of marriage. ${ }^{15}$

\footnotetext{
${ }^{14}$ Interview with Asman Hatta, the Founder of the Suku Anak Dalam community.

${ }^{15}$ Anonim, p. 44.
} 
The nature of marriage in the Suku Anak Dalam community can be seen from three aspects, such as:

a. Bride-exchange is the exchange of daughters between one with another group;

b. Bride-service is a customary principle that must be implemented. The tradition of following prospective in-laws for at least one season. During this time, he must be able to prove that he is a responsible household head and a good prospective son-in-law. Prospective parents-in-law will assess whether the prospective sonin-law is appropriate or not to marry his daughter;

c. Bride-price. Marriage can occur or it is permissible to choose the preferred wife candidate without being prohibited. But for women it is forbidden to marry outsiders or from different ethnic groups. ${ }^{16}$

According to Muntholib in his dissertation, he stated that the marriage system among the Suku Anak Dalam community tradition adheres to an endogamy system, which requires a person to find a mate in their social environment, relatives, social class or neighborhood. The Suku Anak Dalam emphasizes that marriage must be carried out by the Inner Suku Anak Dalam. They do not want their children and families to marry someone who is not coming from the Outer Suku Anak Dalam. This is also of course forbidden for everyone who comes from outside of the forest who they call the outsiders to marry forest people (Orang Rimba). Even if this happens, there will be consequences of punishment that will be imposed on those who violate these law customs. These punishments will be imposed on both parties, both the outsiders and insiders. ${ }^{17}$

The prohibition on marriages between the Suku Anak Dalam and the outsiders is not solely to uphold the custom laws of their ancestors, but it goes further than that as a form of maintaining their identity as the Suku Anak Dalam. ${ }^{18}$ They live in the jungle, grow up, and die in

${ }^{16}$ Muntholib, 'Orang Rimbo: Kajian Struktural-Fungsional Masyarakat Terasing Di Makekal Propinsi Jambi’ (Universitas Padjajaran, 1995).

${ }^{17}$ Munthalib, p. 116.

${ }^{18}$ Mourad Aribi, Badr-Eddine Sari, and Badia Saari, 'Effect of Endogamy and Consanguinity 
the jungle. For them, the jungle is something very precious that must be defended from all kinds of disturbance or destruction. ${ }^{19}$

In the case of the prohibition of marriage, the Suku Anak Dalam community knows the The Eight Highest Customary Law (Pucuk Undang Nang Delapan), which consists of four laws and above, such as:

1. Looking for Eggs. It literally means breaking the eggs yourself. This term was borrowed to indicate a prohibited act, namely not being allowed to marry one's own child;

2. Stabbing the Earth. It literally means to stick a sword or the like into the ground. This term is borrowed to indicate an act which is prohibited, that is, it is prohibited to marry the mother of a woman or her own mother;

3. Melebung or Cutting a Sprig of Flower. It literally means picking a flower which is used to indicate that you are not allowed to marry your own siblings;

4. Bathing in Ivory Showers. It means that we cannot be allowed to marry someone's wife or wife. ${ }^{20}$

The violation of the four laws will be punished like dead gold, paid or not be paid, someone must be punished until die or the customary law cannot be paid as well as he/she still must be punished until dead). However, through the entry of external influences and the presence of social interactions with the immigrant communities and the increasingly massive, especially since the government-run transmigration program in the early 1980s, it has had an influence in the process of cultural diffusions, especially the presence of the plantation industry has abolished the social institutions of the Suku Anak Dalam community. As the implication, according to the costumary law, the marriage must be in

on the Development of LabialVenous Malformations in Rea of Tlemcen (West Algeria)', The Open Genomics Journal, 1.1 (2008), 1-8 (pp. 1-8) <https://doi.org/10.2174/1875693x00801010001>.

${ }_{19}$ Every religion teaches to protect and preserve nature and to oppose environmental damage Samuel Snyder, 'New Streams of Religion: Fly Fishing as a Lived, Religion of Nature', Journal of the American Academy of Religion, 75.4 (2007), 896-922 <https://doi.org/10.1093/ jaarel//fm063>.

${ }^{20}$ Anne Erita Berta, 'Anne Erita Berta, 'Women and Change among Orang Rimba,' (Departemen of Social Anthropology University of Oslo, 2014). 
accordance with their religion, but their principal character must be also in accordance with the custom laws of their ancestors. This is because they are afraid of being sanctioned by their customary authorities.

\section{Determinant Factors of the Shifting View of the Prohibition of Exogamous Marriage}

According to Islamic law and the formal regulations in Indonesia, there is no obstacle for men and women who are bound by cousin kinship to get married. According to Mahyuda, the law of cousin marriage is permissible $(m u b \bar{a} h)$, because there are no verbal texts in the Quran and Hadith that explicitly recommend or prohibit marriage between cousins. However, Islamic law it explained that marriage between people who are far from the Sunnah is legal. For benefit, Islamic law recommends avoiding marriages between cousins whose kinship is closer. ${ }^{21}$

The positive implication of endogamous marriage in the Suku Anak Dalam community is to maintain the local wisdom values of the community or group. With the preservation of inter-ethnic marriages, of course, the cultural heritage (arts, cultural rituals, and language) can be more preserved and sustainable when compared to the presence of cultural assimilation or unification) through a marriage that we are familiar with as mixed marriage.

The advantages of endogamous marriage and relatives are seen from several advantages according to social and economic points. In many societies, people who are unable to provide a sufficiently large dowry can choose to marry in the family to save themselves the expense. Besides that, there are also other advantages, namely to protect property or to maintain family wealth, and other benefits to protect the offspring so that they are not cut off. Meanwhile, for the tribe of children, endogamy marriages are maintained not only to uphold the customs of their ancestors, but will also destroy the pattern of their life, resulting in disrupted social structures and unbalanced life. Besides that, it is also an effort to maintain

${ }^{21}$ Mahyuda, "Perkawinan Antara Sepupu”' < dari http://www.pabukittinggi.go.id/index. php? option=com_content\&task=view\&id=107\&Itemed $=1>$. 
their identity as the Suku Anak Dalam. They live in the jungle, grew up in the jungle and died in the jungle. ${ }^{22}$

In reality, there is also some of the Suku Anak Dalam who robs or throws away their customs. Eliminating the custom means someone or group of those who have been strong in adhering to the customs of their ancestors and then changes their identity to become a new identity. It means that they become like most people, live or live permanently, and adhere to a religion recognized by the state. As like happened to the Orang Rimba in Air Panas Village, most of them have embraced Islam and have acculturated with the surrounding community. Air Panas Village is inhabited by 50 families with a total of 199 people, consisting of 30 families of the Suku Anak Dalam (118) and 20 families of other ethnic groups (Javanese, Malay, Palembang Malay, and Batak). Likewise in Mestong Subdistrict, the majority of Suku Anak Dalam has embraced Islam with 73 families of the Suku Anak Dalam in Nyogan Village, 68 families of the Suku Anak Dalam (254 persons) in Pelempang Village, and 71 families of the Suku Anak Dalam (263 persons). ${ }^{23}$

Even though their life patterns have changed, there are some customs that have not been touched by these changes. Until now, they have still steadfastly maintained their customs and traditions, especially regarding on local wisdom contained therein such as the culture of preserving nature. ${ }^{24}$ There are several factors behind the Suku Anak Dalam community in conducting endogeneous marriages, such as:

1. Geographical Factor

Endogamous marriages occured among the Suku Anak Dalam community may be influenced by geographic factors, because they are living in the forest (jungle), thus making the place isolated. Besides, the distance between the residence of the Suku Anak Dalam

${ }^{22}$ Every religion teaches to protect and preserve nature and to oppose environmental damage Steven Sager, 'The Sky Is Our Roof, the Earth Our Floor Orang Rimba Customs and Religion in the Bukit Duabelas Region of Jambi, Sumatra', May, 2008.

23 'Document at Mestong Disctrict Office', (Muaro Jambi.).

${ }^{24}$ Kashif M. Sheikh, 'Involving Religious Leaders in Conservation Education in the Western Karakorum, Pakistan', Mountain Research and Development, 26.4 (2006), 319-22 (pp. 319-22) <https://doi.org/10.1659/0276-4741(2006)26[319:IRLICE]2.0.CO;2>. 
community and the village is very far. The larger a community group, the more difficult it is for people to identify and recognize each other among group members.

\section{Custom}

The Suku Anak Dalam community emphasizes that marriage must be carried out by each other. They do not want their childrens and families to marry everyone who are not from the Suku Anak Dalam. Even if this happens, he or she will be punished by legal costum consequences, which will be imposed for everyone who violate these customs. These punishments will be imposed on both parties, both from the insiders themselves and from the outside parties. ${ }^{25}$ There are several legal sanctions that will be given to anyone who violates the customary provisions that have been determined and enforced from generation to generation by their ancestors, namely a fine of 60 pieces of cloth and both men and women must stay in the jungle. According to Tumenggung Tarib, the rules regarding on the prohibition of the marriage of the Suku Anak Dalam with the outsiders are not merely to uphold the custom law of their ancestors, but are further than that as a form of maintaining their identity as jungle people. They live in the jungle, grow up and die in the jungle. ${ }^{26}$

\section{Education}

One of the determinant factors behind the occurrence of endogamous marriages among the Suku Anak Dalam community is the educational factor. This is because the low level of education causes the knowledge of the Suku Anak Dalam community about the impact of endogamous marriages to be minimal. Meanwhile, the people who have a high level of education have the view that endogamy marriages only reduce a social relationships and the worst impact is that the resulting offspring can experience physical disabilities. So it can be emphasized that the low level of education causes a

\footnotetext{
25 Munthalib, p. 116.

${ }^{26}$ Interview with Tumenggung Tarib.
} 
narrow mindset of society and a mindset for the future is less. As stated by Gunawan, "education is an important role in shaping a person's personality traits which can also be influenced by education from school as one of the impacts of getting knowledge".

4. Matchmaking

For the Suku Anak Dalam community, looking for a mate will be better if in their own territory. So it is not surprising that there are many endogamous marriages that are caused by matchmaking. Because looking for a soul mate in one's own sphere has a high probability that the soul mate is from one's own family which will lead to an endogamous marriage. The objectives of the matchmaking include safeguarding property or maintaining family wealth, and other benefits to keep offspring so that they are not cut off. ${ }^{27}$

5. Protecting the Forest or Property

One of the reasons for the Suku Anak Dalam community in conducting endogamous marriages is motivated by their concern about the forest they control. Because if there are no sanctions that prohibit marriage with outsiders, they are worried that outsiders will abuse them as a tool to enter and take or clear the forest for temporary purposes. They live in the jungle, grow up and die in the jungle. For them the jungle is something very precious that must be defended from all kinds of disturbance or destruction. ${ }^{28}$

Based on the data obtained by researchers in this field, some of the informants revealed that the reasons for their exogamous or mixed marriages were based on the wishes and choices of each individual. These informants have their own point of view in choosing and determining who and how their life partner is. There are several factors behind the Suku Anak Dalam in conducting exogamous marriages. The factors include several aspects, such as:

${ }^{27}$ Alexander A. Weinreb, 'Characteristics of Women in Consanguineous Marriages in Egypt, 1988-2000', European Journal of Population / Revue Européenne de Démographie, 24.2 (2008), 185-210 (pp. 185-210) <https://doi.org/10.1007/s10680-008-9160-z>.

${ }^{28}$ Every religion teaches to protect and preserve nature and to oppose environmental damage Snyder. 
1. The pattern of life has changed from moving in the forest to being sedentary. With this sedentary life, the influence of the daily social environment is the reason why they choose to carry out exogamous marriages, which in this case are considered to have deviated from the tradition of marriage that has been carried out so far.

In order to avoid cultural clashes that lead to racial and religious conflicts, the people of the Suku Anak Dalam community try to adapt to the community where they live and always adhere to the traditional seloko "Where the earth is stepped, the sky is upheld, where the sky is respected where the plants grow". The meaning of this saying is that wherever we are, we must be able to adapt to the traditions that apply in that place. For instance, the marriage case in a few years ago when Tumenggung Tarib married his son to a resident of Pematang Kabau Village. For the wedding, Tumenggung Tarib held a party twice. The first party was held in the Suku Anak Dalam area with the term ransom (Bebalai). This party is held to entertain the entire of the Suku Anak Dalam community which is part of the customs of the Suku Anak Dalam. The second party was held in Pematang Kabau Village by inviting the villagers around it. According to Tumenggung Tarib, the marriage process was carried out twice as a way to be able to live side by side with the people around them.

2. Economic influence and life demands. At first, the Suku Anak Dalam community has a closed characteristic and also afraid of the outside community. However, with the extinction of the prey and forest products that have been cut down, the life of the Suku Anak Dalam is threatened. This threat made the Suku Anak Dalam start in looking for a new life and opened by themselve to being able to get to know the outside cultures. This has made the Suku Anak Dalam begin to interact with the outside community in order to make ends meet. In the field of marriage, there has also been a change in mindset, namely marriage of ethnic children with outsiders, which according to customary provisions is prohibited, then becomes permissible. They began to accept with whom and from which circle their partner came from. 
3. The influence of the internal education they receive. Education has a major influence on the life of the Suku Anak Dalam community. Education is an institution that can act as an agent for reform or social change and at the same time determines the direction of social change which is known as community development. Education since then until now is the most important thing in human life. Because education advances the thinking of mankind, so that their standard of living increases. According to Rosmiyati, before he served as head of the sub-village of the Suku Anak Dalam community in Senami village, he was also less enthusiastic about studying at school. However, because he has the same vision as the village head, his program to empower Suku Anak Dalam gets full support. Previously they did not want to go to the puskesmas, but now they want to go to the puskesmas, and they want to enroll their children in the school. ${ }^{29}$

4. Religious conversion is also the reason for their exogamous marriage. Religious differences often become a barrier for someone to unite their love in a marriage bond and religious conversion is the best choice for someone to overcome these differences. Based on the interview with Abdul Malik before converting to Islam, named Mijak, he converted to Islam in October 2015 and married a Javanese woman. According to him, "previously acquainted with and having a relationship with the Javanese woman, when I was going to apply I was required to convert to Islam first and if not then my application was rejected. ${ }^{30}$

It is also relevant with the Bakhtiar's view, who explained that through religious conversion to facilitate marriage with Muslims. For the Suku Anak Dalam who want to marry a Muslim, they must firstly do a religious conversion and learn Islamic religious knowledge as a requirement for marriage, if it is done well then the marriage will be carried out. ${ }^{31}$ Besides that, according to the interview with Abdullah,

\footnotetext{
${ }^{29}$ Interview with Rosmiyati.

${ }^{30}$ Interview with Abdul Malik.

31 Interview with Bakhtiar.
} 
he explained that the first marriage between the Suku Anak Dalam community in Air Hitam District and the outsiders took place on March 28, 2000, namely the marriage between Na'im and Romiyati. Na'im comes from the Suku Anak Dalam community who has converted to Islam and lived permanently in TSM Air Panas, while Romiyati is the son of a trans-Javanese from the Mentawak village. The wedding ceremony was conducted according to local village customs with financial support from PT. SAL and was attended completely by the officials from the Sub-District and the surrounding community. ${ }^{32}$

Based on the above explainations, it can be emphasized here that religious conversion is one of the ways for the Suku Anak Dalam in acculturation with the outside communities. However, before marriage they are required to change their name to Islam. It is make a sense that through the entry of Islam by bringing new teachings to the Suku Anak Dalam culture then influenced the existing traditions. However, the change of the existing culture is an adjustment to the accepted view of religious truth. Thus, the culture of the Suku Anak Dalam comes in the form of the new values and standards with the results of the meeting of two cultures.

\section{Conclusion}

As the result of the research, finally, it can be concluded here that there have been social changes in the Suku Anak Dalam community before and after converting to Islam in the field of Islamic family law, especially in the matters of marriage. In the past, their marriage system adopted an endogamy system, which required someone to find a prospective life partner in their social environment, relatives, social class or neighborhood. However, along with the progress of the era where the level of education, the flow of information and technology as well as the increasing economy of the community have an impact on the shift in mindset and awareness of attitudes that make endogamy abandoned by some of the Suku Anak Dalam people, especially those who have converted to Islam and live in the village. There are also

\footnotetext{
${ }^{32}$ Interview with Abdullah.
} 
several factors behind the Suku Anak Dalam community in conducting exogamous marriages, such as the change of life patters from moving to being sedentary, the influence of the internal education they receive, economic influence and life demands as well as religious conversion which causes them to have exogamous marriages. These factors inhibit the social changes that are the lack or no relationship with other communities, a traditionalist or closed attitude, strong institutionalized customs, and late development of science.

\section{Bibliography}

Anne Erita Berta, 'Anne Erita Berta, 'Women and Change among Orang Rimba,' Departemen of Social Anthropology University of Oslo, 2014. Anonim, Buku Pedoman Adat Jambi. Jambi: Lembaga Adat Province of Jambi, 1994.

Aribi, Mourad, Badr-Eddine Sari, and Badia Saari, 'Effect of Endogamy and Consanguinity on the Development of LabialVenous Malformations in Rea of Tlemcen (West Algeria)', The Open Genomics Journal, 1.1 (2008), 1-8 <https://doi.org/10.2174/1875693x00801010001>

Aritonang, Robert, Pengetahuan Lokal Orang Rimba Dan Implikasinya Pada Strategi Berburu Dan Meramu. Jakarta: Ministry of Enviroment Republic of Indonesia, 2004.

'Central Bureau of Statistics', Jambi, 2020.

'Document at Mestong Disctrict Office', Muaro Jambi.

Interview with Abdul Malik.

Interview with Abdullah

Interview with Asman Hatta, the Founder of the Suku Anak Dalam community

Interview with Bakhtiar.

Interview with Rosmiyati

Interview with Tumenggung Tarib

Mahyuda, "Perkawinan Antara Sepupu”" < dari http://www.pabukittinggi. go.id/index.php? option=com_content\&task=view\&id=107\&Itemed=1> Mukhlas, Tambo Anak Dalam Jambi: NP, t.t. 
Munthalib, Suku Anak Dalam Di Pinggiran Kawasan Hutan Lindung Taman Nasional Bukit XII Propinsi Jambi. Serang: A Empat, 2014.

Muntholib, 'Orang Rimbo: Kajian Struktural-Fungsional Masyarakat Terasing Di Makekal Propinsi Jambi'. Universitas Padjajaran, 1995.

Ni'am, Asrorun. Fatwa-Fatwa Masalah Pernikahan Dan Keluarga. Jakarta: Graha Paramuda, 2008.

Sager, Steven, 'The Sky Is Our Roof, the Earth Our Floor Orang Rimba Customs and Religion in the Bukit Duabelas Region of Jambi, Sumatra', May, 2008

Saudagar, Fachruddin, 'Masyarakat Kubu Di Jambi', in Profil Masyarakat Hukum Adat Tradisional Di Nusantara Dari Aceh Sampai Papua, Ttp: Tnp, t.t.

Suma, Muhammad Amin, Hukum Keluarga Islam Di Dunia Islam, Jakarta: Raja Grafindo Persada, 2004.

Seloa dan Meliani, Masyarakat Terasing Suku Anak Dalam. Jakarta: Direktorat Bina Masyarakat Terasing, 1998.

Sheikh, Kashif M., 'Involving Religious Leaders in Conservation Education in the Western Karakorum, Pakistan', Mountain Research and Development, 26.4 (2006), 319-22 <https://doi.org/10.1659/02764741(2006)26[319:IRLICE]2.0.CO;2>.

Shulhan, Muwahid, 'Rekonstruksihukum Islam dan Implikasi Sosial Budaya Pasca Reformasi Di Indonesia', KARSA: Journal of Social and Islamic Culture, 20.2 (2013), 176-96 <https://doi.org/10.19105/karsa.v20i2.41>

Snyder, Samuel, 'New Streams of Religion: Fly Fishing as a Lived, Religion of Nature', Journal of the American Academy of Religion, 75.4 (2007), 896-922 <https://doi.org/10.1093/jaarel/lfm063>

Soemardjan, Selo, Perubahan Sosial Di Yogyakarta. Yogyakarta: Gajah Mada University Press, 1990.

Soekanto, Meninjau Hukum Adat Indonesia, Suatu Pengantar Untuk Mempelajari Hukum Adat. Jakarta: Rajawali Press, 1981.

Weinreb, Alexander A., 'Characteristics of Women in Consanguineous Marriages in Egypt, 1988-2000', European Journal of Population / Revue Européenne de Démographie, 24.2 (2008), 185-210 <https:// doi.org/10.1007/s10680-008-9160-z> 